\title{
DNA methylation analysis of the tumor suppressor gene CDKN2B in Brazilian leukemia patients
}

\author{
Patrícia Santos Pereira Lima ${ }^{1,2}$, Greice Andreoti Molffeta ${ }^{2}$, Amélia Góes de Araujo ${ }^{3,4}$, \\ Marco Antônio Zago ${ }^{3,4}$ and Wilson Araújo da Silva Jr., \\ ${ }^{I}$ Departamento de Ciências Naturais, Universidade Estadual do Sudoeste da Bahia, \\ Vitória da Conquista, BA, Brazil. \\ ${ }^{2}$ Laboratório de Genética Molecular e Bioinformática, Departamento de Genética, \\ Faculdade de Medicina de Ribeirão Preto, Universidade de São Paulo, Ribeirão Preto, SP, Brazil. \\ ${ }^{3}$ Departamento de Clínica Médica, Faculdade de Medicina de Ribeirão Preto, \\ Universidade de São Paulo, Ribeirão Preto, SP, Brazil. \\ ${ }^{4}$ Centro de Terapia Celular and Centro Regional de Hemoterapia, \\ Faculdade de Medicina de Ribeirão Preto, Universidade de São Paulo, Ribeirão Preto, SP, Brazil.
}

\begin{abstract}
The aim of this work was to evaluate the methylation profile of the $p 15$ (CDKN2B) gene in Brazilian patients with leukemia and to correlate the CDKN2B gene expression with the percentage of methylated CpG dinucleotides in its promoter region. Thirty-one samples from six patients with acute lymphocytic leukemia (ALL), four with chronic myeloid leukemia (CML), and 21 with acute myeloid leukemia (AML) were evaluated by MSP (Methylation-Specific PCR). The CDKN2B gene was found to be methylated in four (67\%) of the six ALL samples and in $16(76 \%)$ of the $21 \mathrm{AML}$ samples, but in none of the four CML samples analyzed. We observed a correlation between the CDKN2B mRNA expression (RT-PCR) and the percentage of methylated CpG dinucleotides. Therefore, this study in Brazilian patients confirms that the $C D K N 2 B$ gene is methylated in the majority of leukemia patients.
\end{abstract}

Key words: CpG island, DNA methylation, $C D K N 2 B$.

Received: August 23, 2007; Accepted: March 10, 2008.

\section{Introduction}

DNA methylation is a covalent modification and results from the activity of a family of DNA methyltransferase (DNMT) enzymes which catalyze the transfer of a methyl group ( $\mathrm{CH} 3)$ from $\mathrm{S}$-adenosylmethionine (SAM) to the cytosine residues at $\mathrm{CpG}$ dinucleotides (Strathdee and Brown, 2002). The distribution of $\mathrm{CpG}$ dinucleotides in the human genome is not uniform, but there are small stretches ( $0.5 \mathrm{~kb}$ to several $\mathrm{kb})$ of $\mathrm{CpG}$-rich DNA regions termed $\mathrm{CpG}$ islands (Galm et al., 2006). It has been estimated that the human genome contains about 29,000 CpG islands (Nephew and Huang, 2003). These CpG islands are usually located in the vicinity of genes, are often found near the promoters of widely expressed genes, and typically extend into the first exon (Jones, 2003). In contrast to CpG dinucleotides, which are dispersed throughout the genome, the

Send correspondence to Patrícia Santos Pereira Lima. Laboratório de Genética Molecular e Bioinformática, Fundação Hemocentro de Ribeirão Preto, Rua Tenente Catão Roxo 2501, 14051-140 Ribeirão Preto, SP, Brazil. E-mail: psplima@rge.fmrp.usp.br. cytosines within $\mathrm{CpG}$ islands, especially those associated with promoter regions, are normally unmethylated, allowing the expression of a gene. The exception to this unmethylated state of $\mathrm{CpG}$ islands involves the imprinted genes and $\mathrm{X}$-chromosome inactivation, and this indicates the tight association of promoter DNA methylation with transcriptional silencing during normal mammalian development (Galm et al., 2006).

The methylation pattern of normal cells is kept through successive cellular divisions in adult tissues and the heritage of this information is called epigenetic inheritance (Laird, 2003). Therefore, epigenetics is the study of modifications in gene expression that are not caused by alterations of DNA sequence (Verma and Srivastava, 2002; Galm et al., 2006).

In tumorigenesis, the balance of the methylation state of normal cells is lost, and some of the possible alterations are: (I) transcriptional silencing of tumor suppressor genes by $\mathrm{CpG}$ island promoter hypermethylation; and (II) histone deacetylation and global genomic hypomethylation. Hypo- 
methylation contributes to carcinogenesis and is responsible for the chromosomal instability, reactivation of transposable elements, and loss of imprinting (Esteller and Herman, 2002). Therefore, the profile of hypermethylation promoters differs according to each cancer type, because for each tumor type specific genes are methylated. In addition to that, the epigenetic inactivation may affect all molecular mechanisms involved in cell immortalization and transformation. Last but not least, it seems that epigenetic changes are among the several early steps in carcinogenesis (Mukai and Sekiguchi, 2002).

According to the estimates of cancer incidence for 2008 by INCA (Instituto Nacional do Câncer - Brazilian National Cancer Institute), leukemias will afflict 5220 men and 4320 women. Hematologic neoplasias can jeopardize the lymphoid or myeloid lineages. Lymphoid neoplasias start from lymphoid lineage cells in different stages of maturation. Myeloid neoplasias result from a pluripotential progenitor cell mutation which maintain the capacity, albeit in an imperfect manner, of differentiation and maturation for each one of the myeloid lineages (Zago et al., 2001). Most acute leukemias appear to be the consequence of the collaboration between one class of mutations or gene rearrangements that confer a proliferative and/or survival advantage to hematopoietic progenitors and a second class of mutations that serve primarily to impair hematopoietic differentiation and subsequent apoptosis of cells (Kelly and Gilliland, 2002).

In hematological neoplasms, hypermethylation genes were identified in multiple fundamental pathways related to cancer, including cell cycle control $(p 15, p 16$, $R b 1, p 27, p 73)$, DNA repair $\left(O^{6} M G M T\right)$, apoptosis inhibition $(D A P K)$, tumoral metastasis (E-cadherin), and growth factors (ER, EphA3) (French et al., 2002). One of the most frequent methylated genes in leukemia, mainly in ALM, is CDKN2B (Herman et al., 1996; Issa et al., 1997; Wong et al., 2000; Toyota et al., 2001; Claus and Lubbert, 2003).

In this work, we determined the methylation profile of the $C D K N 2 B$ gene in samples from Brazilian patients with acute myeloid leukemia (AML), acute lymphocytic leukemia (ALL), and chronic myeloid leukemia (CML). We also evaluated the $C D K N 2 B$ mRNA expression and the percentage of methylated $\mathrm{CpG}$ dinucleotides by sequencing of sodium bisulfite-treated DNA.

\section{Material and Methods}

\section{Samples}

Genomic DNA was extracted from bone marrow cells of six ALL patients, four CML patients, 21 AML patients and one sample of normal bone marrow, using a Super Quik Gene Kit (AGTC). The AML samples were subdivided based on French-American-British (FAB) into: M0 (1), M1 (2), M2 (10), M4 (2), M5 (4) and M6 (2). All patients signed a consent form approved by the Ethics Committee of the Institution.

\section{Bisulfite DNA modification}

Bisulfite DNA modification was accomplished in agreement with the technique described in Current Protocols In Human Genetics (Dracopoli et al., 1994). DNA $(2 \mu \mathrm{g})$ was denatured with $\mathrm{NaOH}(2 \mathrm{M})$ for $10 \mathrm{~min}$ at $37^{\circ} \mathrm{C}$. Ten millimoles of hydroquinone and $3 \mathrm{M}$ of sodium bisulfite at $\mathrm{pH} 5$, both freshly prepared, were added and mixed, and then samples were incubated at $50{ }^{\circ} \mathrm{C}$ for $16 \mathrm{~h}$. The modified DNA was purified using a Wizard DNA clean-up purification kit (Promega) according to the manufacturer's instructions and eluted into water. Modification was completed by treatment with $\mathrm{NaOH} 3 \mathrm{M}$ for 5 min at room temperature, followed by ethanol precipitation. The DNA was resuspended in water and used immediately or stored at $-80{ }^{\circ} \mathrm{C}$.

\section{Methylation-Specific PCR (MSP)}

A modified DNA was used for two MSP reactions, both for the $C D K N 2 B$ gene: one reaction specific for methylated DNA and other specific for unmethylated DNA. The primer sequences used were: $C D K N 2 B-\mathrm{F}(\mathrm{M}) 5$ '-CGTTCG TATTTTGCGGTT-3'; $C D K N 2 B$-R(M) 5'-CGTACAATA ACCGAACGACCGA-3'; $C D K N 2 B-\mathrm{F}(\mathrm{U}) 5^{\prime}$ '-TGTGATG TGTTTGTATTTTGTGGTT-3'; and $C D K N 2 B-\mathrm{R}(\mathrm{U})$ 5'CCATACAATAACCAAACAACCAA-3' (Herman et al., 1996). For all reactions the amplification conditions were: bisulfite-modified DNA; 10X PCR buffer (Invitrogen); $50 \mathrm{mM} \mathrm{MgCl} 2 ; 1.25 \mathrm{mM} \mathrm{dNTP}$, and $300 \mathrm{ng} / \mu \mathrm{L}$ of each primer. Reactions were hot-started at $95{ }^{\circ} \mathrm{C}$ for $5 \mathrm{~min}$ before addition of 1.25 units of Taq polymerase (Invitrogen), followed by 35 cycles $\left(30 \mathrm{~s}\right.$ at $95{ }^{\circ} \mathrm{C}, 30 \mathrm{~s}$ at $61{ }^{\circ} \mathrm{C}$ for primer methylated or $60^{\circ} \mathrm{C}$ for primer unmethylated, $30 \mathrm{~s}$ at $72{ }^{\circ} \mathrm{C}$ ), and a final extension step of $4 \mathrm{~min}$ at $72^{\circ} \mathrm{C}$. Each PCR product was analyzed using $3 \%$ agarose gel, stained with ethidium bromide and directly visualized under UV illumination.

\section{Sequencing of sodium bisulfite-treated DNA}

Bisulfite-treated DNA was amplified by a nestedPCR protocol, using the following primers: $C D K N 2 B-\mathrm{F} 1$ 5'-GGTTGAAGGAATAGAAATTT-3' and $C D K N 2 B$-R1 5'-ACACТСТТСССТТСТТТССС-3' for the first reaction; and $C D K N 2 B$-F2 5'-TTAGTTTTGGTTTTATTGG A-3' and $C D K N 2 B$-R2 5'-TCTCTCCTTCCTAAAAAAC C-3' for the second reaction. PCR was performed in a solution containing $10 \mathrm{X}$ buffer (Biotools); $1.25 \mathrm{mM}$ dNTP; $2.5 \mu \mathrm{M}$ of each primer, and $2 \mathrm{U}$ of Taq DNA polymerase (Biotools). The PCR conditions were: $94{ }^{\circ} \mathrm{C}$ for $5 \mathrm{~min}$ and $55^{\circ} \mathrm{C}$ for $2 \mathrm{~min}$, followed by 35 cycles $\left(72^{\circ} \mathrm{C}\right.$ for $1 \mathrm{~min}$, $94{ }^{\circ} \mathrm{C}$ for $1 \mathrm{~min}$, and $55^{\circ} \mathrm{C}$ for $1 \mathrm{~min}$ ) and $72{ }^{\circ} \mathrm{C}$ for $10 \mathrm{~min}$ for the first reaction. For the nested reaction the conditions were similar, only the annealing temperature being chan- 
ged to $51{ }^{\circ} \mathrm{C}$. The amplified products were sequenced directly in a MegaBace 1000 sequencer.

\section{RNA isolation and reverse transcriptase PCR (RT-PCR)}

Total RNA was isolated using TRIZOL (Invitrogen) and the cDNA was synthesized with the use of a High Capacity kit (Applied Biosystems). Amplification of $C D K N 2 B$ mRNA was performed with specific primers: $C D K N 2 B$-RTF 5'-AACGGAGTCAACCGTTTCGG-3' and $C D K N 2 B$-RTR 5'-TGTGCGCAGGTACCCTGCA A-3' (Hoshino et al., 2002). The PCR conditions were as follows: $10 \mathrm{X}$ buffer (Biotools); $1.25 \mathrm{mM}$ dNTP; 20 pmol of each primer, and $2 \mathrm{U}$ of Taq DNA polymerase (Biotools). PCR was initiated with one cycle at $95^{\circ} \mathrm{C}$ for $1 \mathrm{~min}$, followed by 30 cycles at $95^{\circ} \mathrm{C}$ for $1 \mathrm{~min}, 55^{\circ} \mathrm{C}$ for $1 \mathrm{~min}$, and $72^{\circ} \mathrm{C}$ for $1 \mathrm{~min}$. The internal control was the glyceraldehyde 3-phosphate dehydrogenase (GAPDH) gene. The amplified products were analyzed on $1.5 \%$ agarose gel, stained with ethidium bromide and directly visualized under UV illumination.

\section{Results}

\section{Methylation analysis}

Different methylation patterns of the $C D K N 2 B$ gene were detected among leukemia types analyzed by MSP. The gene was methylated in four (67\%) of the six ALL samples and in $16(76 \%)$ of the 21 AML samples, but in none of the four CML samples analyzed. Regarding AML subtypes, the frequency distribution of $C D K N 2 B$ gene methylation was: M0 1/1, M1 2/2, M2 9/10, M4 0/2, M5 3/4, and M6 1/2. In 12 AML samples, amplification was achieved with both primers, specific for methylated DNA and for unmethylated DNA, and therefore these samples were classified as hemimethylated (Figure 1). For frequency estimates, these hemimethylated samples were considered as methylated.

\section{Expression analysis}

The expression of $C D K N 2 B$ mRNA was evaluated in 19 samples with available RNA (six methylated, five unmethylated, and eight hemimethylated) and in one normal bone marrow sample. In the methylated samples, no $C D K N 2 B$ mRNA expression was detected (Figure 2A). On the other hand, $C D K N 2 B$ expression was detected in the unmethylated and in some hemimethylated samples (Figures $2 \mathrm{~B}$ and $\mathrm{C}$ ). However, the level of expression was higher in the unmethylated than in the hemimethylated samples. The highest level of $C D K N 2 B$ gene expression was detected in the normal bone marrow sample.

\section{Sequencing analysis}

The region analyzed (498 bp) after bisulfite treatment of the DNA is located approximately -234 to $+264 \mathrm{bp}$ from the transcription start site, comprising two $\mathrm{CpG}$ islands according to the MethPrimer program (Li and Dahiya, 2002). However, the $\mathrm{CpG}$ dinucleotides analyzed by sequencing contained only the region located -15 to $+208 \mathrm{bp}$ (223 bp) from the transcription start site that shows $26 \mathrm{CpG}$ dinucleotides. The sequence amplified by MSP (147 bp), which shows $19 \mathrm{CpG}$ dinucleotides, is within the sequenced region (Figure 3).

Thirteen out of the 31 samples analyzed by MSP were sequenced (one normal bone marrow, four methylated, four hemimethylated and four unmethylated). The methylation percentage for each sample was calculated as the number of methylated $\mathrm{CpG}$ dinucleotides in the total number of analyzed CpGs (Figure 4). The normal sample did not show any methylated $\mathrm{CpG}$ (data not shown). Seven out of eight samples, which were amplified with the primer set specific for the methylated DNA, presented a methylated $\mathrm{CpG}$ frequency of $46 \%$ to $100 \%$. The exception was sample XIX (Figure 4), considered to be hemimethylated by MSP, which showed only $26 \%$ of methylated $\mathrm{CpG}$ dinucleotides. In the unmethylated samples, the percentage of methylated CpGs ranged from $15 \%$ to $46 \%$.

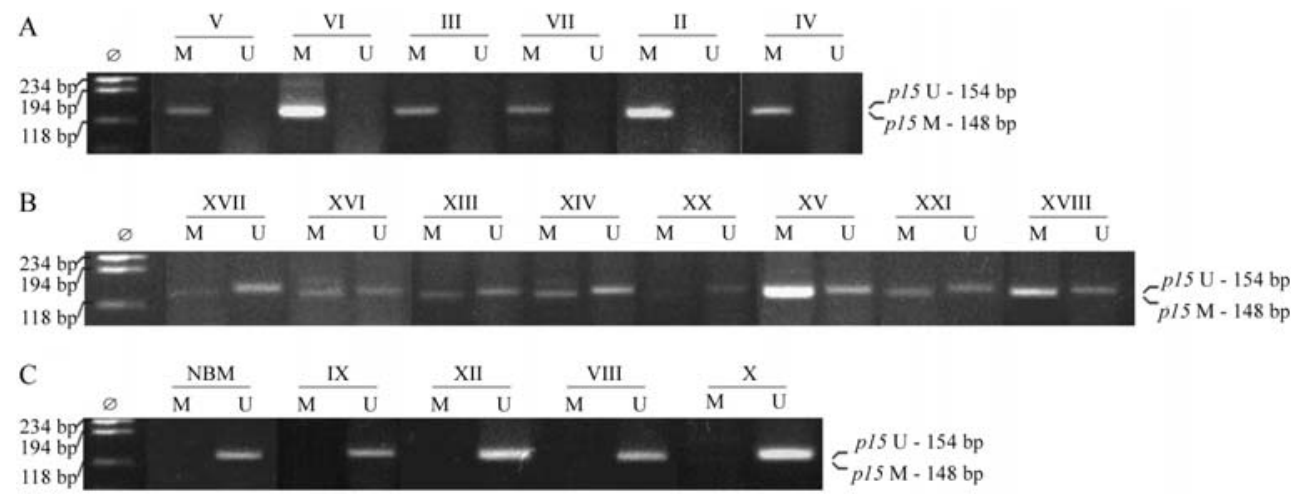

Figure 1 - MSP of $C D K N 2 B$. Primer sets used for amplification are designated as methylated (M) or unmethylated (U). The leukemia samples are represented in Roman numbers. NBM = normal bone marrow. (A) Samples amplified with methylated primer set. (B) Samples amplified with methylated and unmethylated primer sets. (C) Samples amplified with unmethylated primer set. 


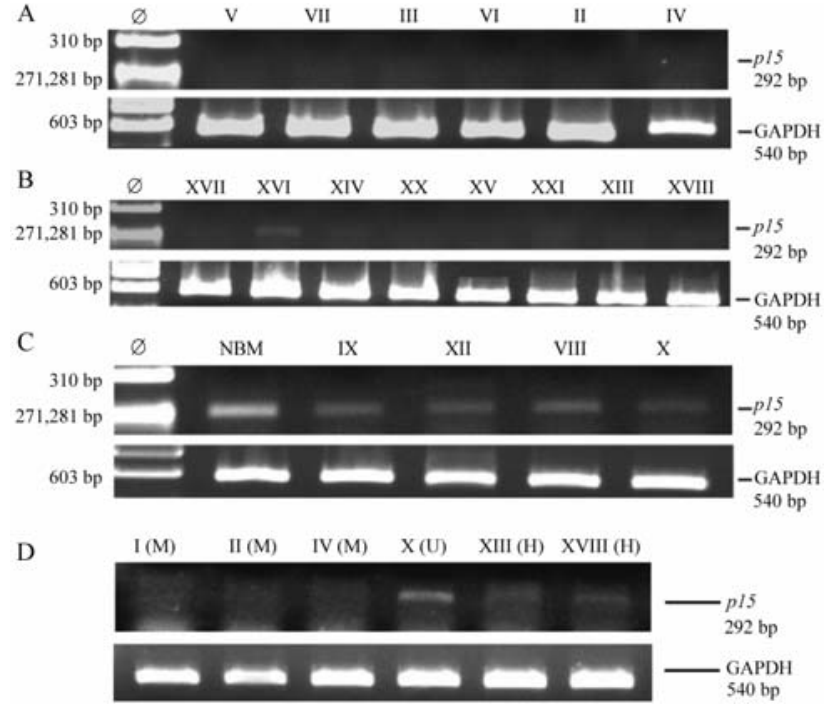

Figure 2 - $C D K N 2 B$ mRNA expression evaluated by RT-PCR. $\mathrm{NBM}=$ normal bone marrow. The samples are represented in roman numbers. (A) methylated samples (B) hemimethylated samples. (C) unmethylated samples. (D) Comparative RT-PCR. GAPDH was used to control the integrity of the RNA samples.

\section{Discussion}

The $C D K N 2 B$ gene encodes a $15-\mathrm{kDa}$ protein that is a cyclin-dependent kinase inhibitor. The role of $C D K N 2 B$ as a tumor suppressor in acute myelogenous leukemia (AML) was established in several previous studies (Herman et al., 1996; Issa et al., 1997; Wong et al., 2000; Toyota et al., 2001; Claus and Lubbert, 2003). Hypermethylation of $C D K N 2 B$ CpG islands has been shown to occur in up to $80 \%$ of human AML, and this epigenetic state is associated with reduced expression (Markus et al., 2007).

In this study, analysis results of the methylated state of the $C D K N 2 B$ gene, performed by MSP, were confirmed by direct sequencing and expression analysis. Our MSP results showed that $C D K N 2 B$ was methylated in $76 \%$ of the AML samples. These results are in agreement with previous studies that found the $C D K N 2 B$ gene to be methylated in more than $50 \%$ of the cases (Herman et al., 1996; Issa et al., 1997; Toyota et al., 2001; Claus and Lubbert, 2003).

Among patients with AML, Wong et al. (2000) reported $C D K N 2 B$ methylation frequencies to be higher in subtypes M2, M3 or M4 than in M1, M5, M6 or M7. In nine of our 10 subtype M2 samples, the gene was methylated; for the other subtypes, the number of samples was too small to allow a correlation analysis.

In ALL, previous studies indicated different methylation frequencies for the $C D K N 2 B$ gene, depending on the methodology used (Issa et al., 1997; Melki et al., 1999; Garcia-Manero et al., 2002; Melki and Clark, 2002; Chim et al., 2003). We found a higher frequency (67\%) than that (40\%) described by Chim and colleagues (2003), using the same methodology (MSP). This might be due to our smaller sample size (six samples) compared to theirs ( 25 samples). Even with a small number of LMC samples (four), our data showed the unmethylated state of the CDKN2B gene, which is in agreement with previous reports (Issa et al., 1997; Toyota et al., 2001).

A sample of genomic DNA usually consists of a large pool of molecules that may display methylation heterogeneity. This heterogeneity can be due to the fact that two alleles of any given genomic locus in a cell may differ in their methylation patterns, and that the DNA sample was derived from multiple cells with potentially different methylation patterns (Siegmund and Laird, 2002). This could explain the simultaneous amplification by MSP using primer sets for both methylated and unmethylated DNA. This methylation heterogeneity of samples can also be difficult to analyze by direct sequencing of sodium bisulfite-treated DNA, once it does not allow the methylation state of individual alleles to be determined. Hence, in some chromatograms the
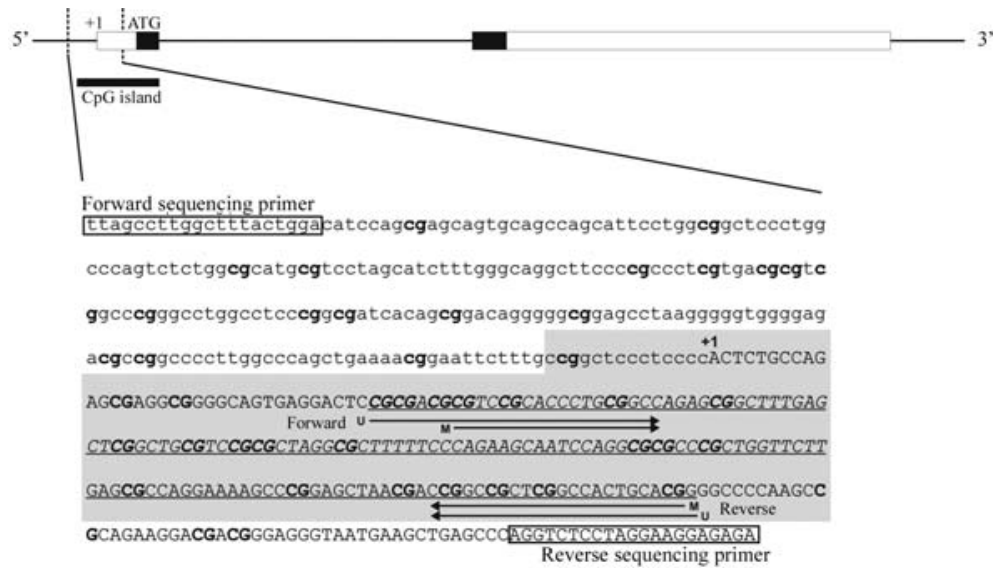

Figure 3 - $C D K N 2 B$ gene sequence amplified by nested-PCR. The sequence analyzed by direct sequencing is highlighted in gray. The region amplified by MSP is underlined. Intron sequences, in short letters, exon sequences, in capital letters, and CpG dinucleotides in boldface. RefSeq accession NM_004936. 


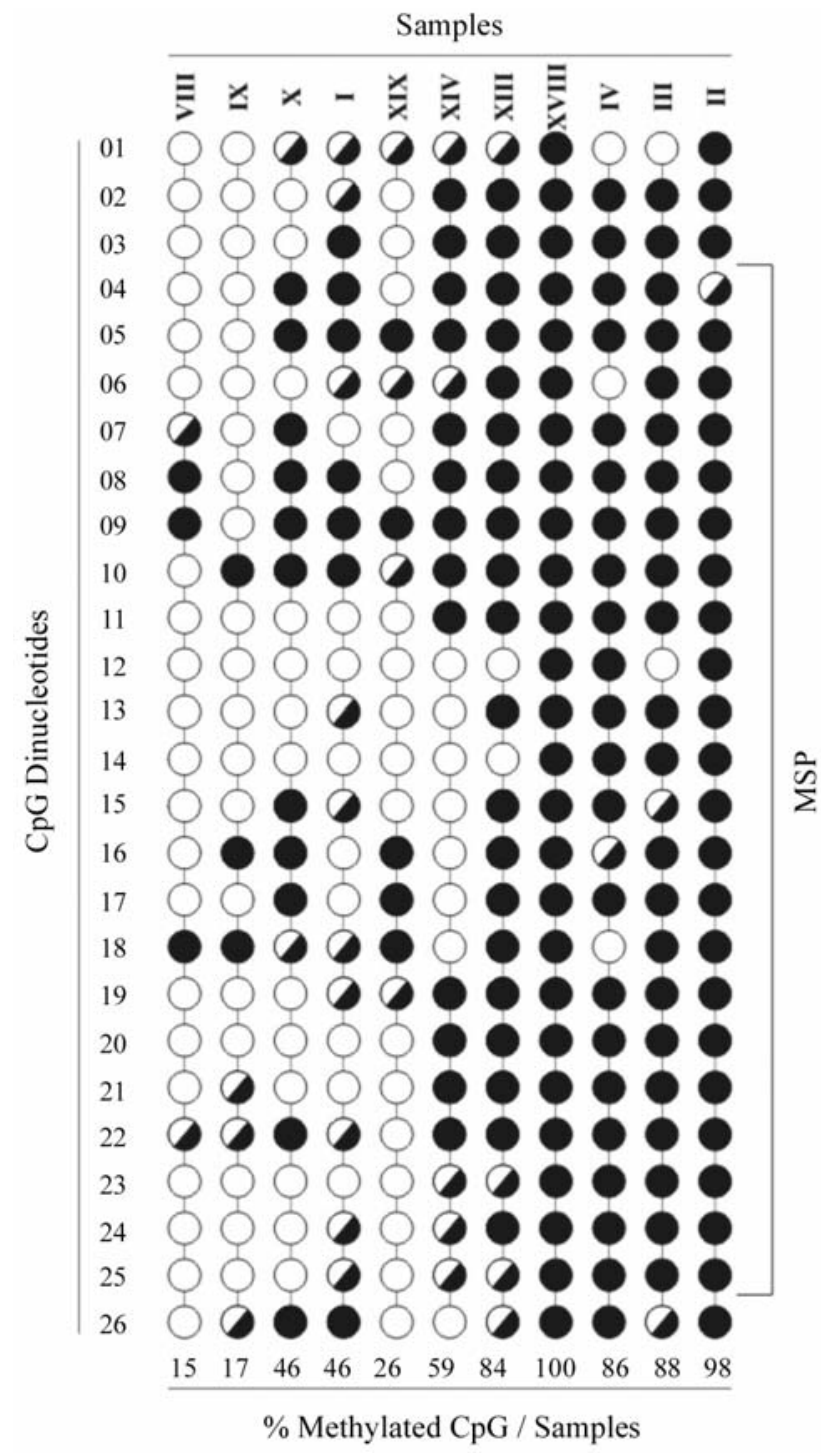

Figure 4 - Scheme of direct bisulfite sequencing of region containing 26 $\mathrm{CpG}$ dinucleotides. Each circle represents a $\mathrm{CpG}$ dinucleotide. Spacing between circles is relative. Open circle, unmethylated; black circle, methylated; partly open circle, hemimethylated. M, methylated; $U$, unmethylated and $\mathrm{H}$, hemimethylated. The numbers at the top indicate the samples: VIII, IX and X are unmethylated; XIII, XIV, XVIII and XIX, hemimethylated; I, II, III and IV, methylated. The numbers to the left indicate the $\mathrm{CpG}$ dinucleotides, and those below, the percentage of methylation in each sample. The $\mathrm{CpG}$ dinucleotides amplified by MSP are shown on the right.

TCpG sequence was observed instead of TpG or CpG. We expected to find $\mathrm{TpG}$ in the case of an unmethylated dinucleotide and $\mathrm{CpG}$ in the case of a methylated dinucleotide. The term hemimethylated was also used to designate those $\mathrm{CpG}$ nucleotides for which the methylation state could not be defined by sequencing, as it occurred in $\mathrm{CpG}$ 04, 06 and 10 (Figure 5C).

In general, the amount of methylated $\mathrm{CpG}$ sites within a locus, as well as the number of methylated loci, increase in more advanced stages of cancer (Nephew and Huang, 2003). The consequence of this dynamic epigenetic gene silencing is that the degree of loss of protein production is not uniform throughout the tumor-cell population, unlike the one that is produced by the genetic changes (Jones and Baylin, 2002). We analyzed the expression of $C D K N 2 B$ mRNA, which in general agreed both with the MSP results and with the percentage of methylated $\mathrm{CpG}$ dinucleotides, as determined by direct PCR sequencing. In the methylated samples that showed more than $80 \%$ of methylated $\mathrm{CpG}$ dinucleotides, no $C D K N 2 B$ mRNA expression was observed by RT-PCR (Figures 2A and 4). In the unmethylated samples, a relationship between the expression level and the percentage of methylated $\mathrm{CpG}$ was observed, as in sample $\mathrm{X}(46 \%$ methylated $\mathrm{CpG})$ and samples VIII and IX (15\% and 17\% methylated CpG, respectively) (Figures 2C and 4). The CDKN2B gene expression was very low when the gene was found to be hemimethylated by MSP (Figure 2B). CDKN2B mRNA expression differed between the normal bone marrow and the unmethylated samples (Figure 2C). These unmethylated samples showed a low percentage of methylated $\mathrm{CpG}$, which seems to correlate with the levels of mRNA transcription.

The percentage of methylated CpGs was similar $(46 \%)$ in samples X and I (unmethylated and methylated, respectively). However, their level of gene expression and the number of hemimethylated CpGs (Figures 2D and 4) were different. There were 10 hemimethylated CpGs in sample I, while in sample X only 2 hemimethylated CpGs were identified. Hence, the methylation density of the region analyzed was higher in sample I than in sample $\mathrm{X}$, and this might have caused the apparent difference in $C D K N 2 B$ gene expression observed between these samples.

Another difference between the samples was the state of the methylated $\mathrm{CpG} 3$ dinucleotide at the transcription factor $\mathrm{Sp} 1$ site. Sp1 is associated with the transcription of the $C D K N 2 B$ gene and is a regulator of cell cycle progression (Pagliuca et al., 2000). Many factors are known to bind CpG-containing sequences, and some of them fail to bind when the $\mathrm{CpG}$ is methylated, therefore inhibiting transcription (Bird, 2002). CpG 3 and $\mathrm{CpG} 25$ are part of two Sp1 sites (Figure 4), and in seven of the eight sequenced samples which were amplified by the specific primer set for methylated DNA at least one of these dinucleotide CpGs was methylated (Figure 4).

Methylation of specific targets may explain the observation that different hematopoietic malignancies harbor distinct methylation signatures (Rush and Plass, 2002). The cell type-specific pattern of hypermethylation suggests that the methylation of certain $\mathrm{CpG}$ islands may be used as disease marker and is also useful in the detection of minimal residual disease after chemotherapy. This pattern may therefore influence any adjuvant treatments (Melki and Clark, 2002) or be used as a marker for disease progression (Laird, 2003). Agrawal et al. (2007) showed increased $C D K N 2 B$ methylation levels in the bone marrow of patients 


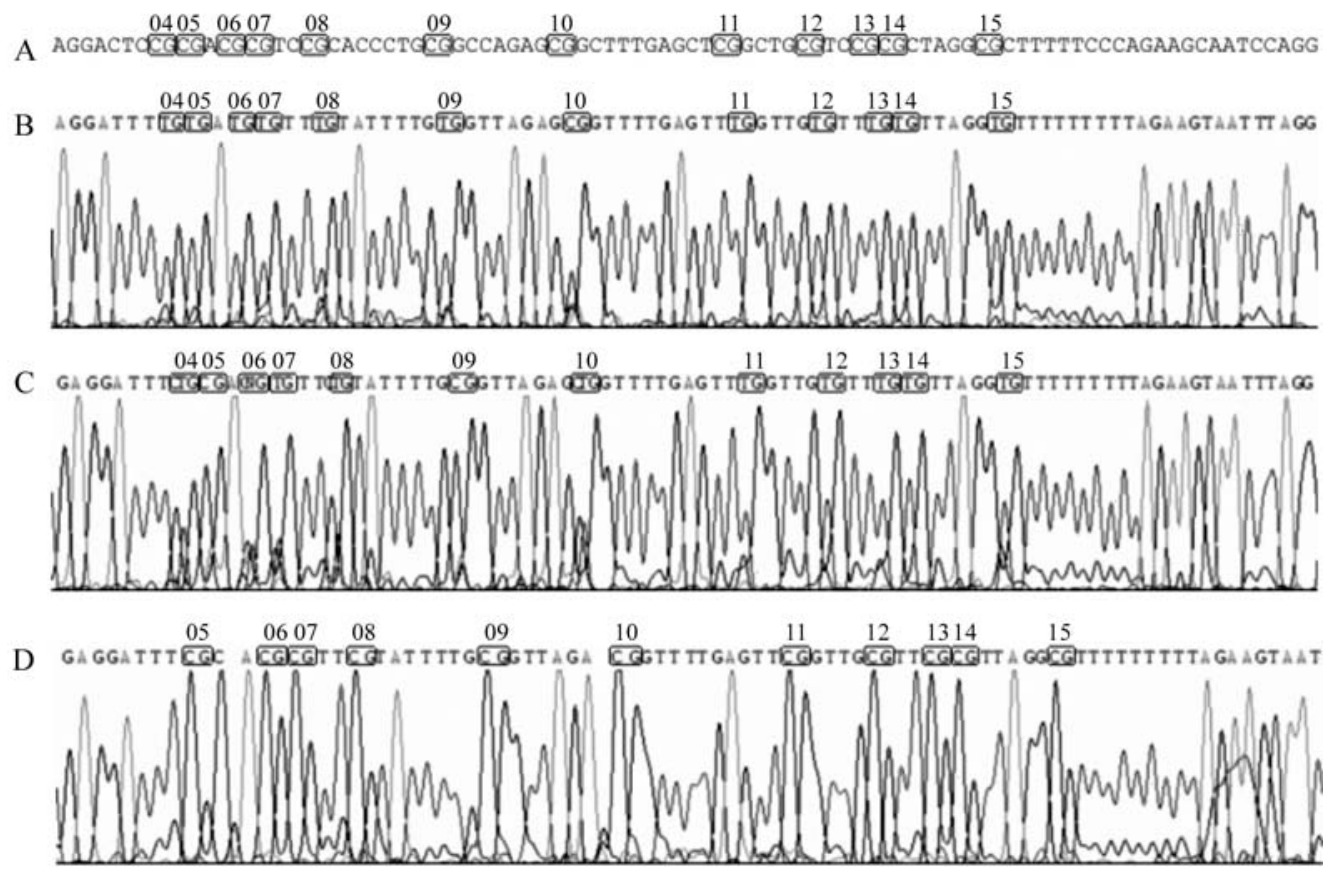

Figure 5 - Chromatogram of the direct bisulfite sequencing from $\mathrm{CpG} 4$ to $\mathrm{CpG} 15$ of the region: (A) Original sequence. (B) Sample IX, unmethylated. (C) Sample XIX, hemimethylated. (D) Sample II, methylated. The CpG dinucleotides are highlighted. After bisulfite treatment, the CpG dinucleotides remained as such in the methylated samples, but were converted to $\mathrm{TpG}$ in the unmethylated samples. In the hemimethylated samples, some $\mathrm{CpG}$ dinucleotides were converted but others not.

with acute leukemias in clinical remission and, according to these authors, the presence of aberrant DNA methylation in remission is a powerful indicator of a high risk of leukemia relapse.

In this first report on the methylation status of the $C D K N 2 B$ gene in Brazilian leukemia patients, $C D K N 2 B$ was found to be methylated, in agreement with data obtained in similar analyses performed in leukemia patients of other countries.

\section{Acknowledgments}

Support for this work was provided by the Brazilian agencies FAPESP, CNPq, Center for Cell-based Therapy and UESB. We also thank Marli H. Tavella, Cristiane F. Ayres, Adriana A. Marques and Anne Marie R. D. dos Santos for their excellent technical assistance.

\section{References}

Agrawal S, Unterberg M, Koschmieder S, Stadt UZ, Brunnberg U, Verbeek W, Buchner T, Berdel WE, Serve H and Muller-Tidow C (2007) DNA methylation of tumor supressor genes in clinical remission predicts the relapse risk in acute myeloid leukemia. Cancer Res 67:1370-7.

Bird A (2002) DNA methylation patterns and epigenetic memory. Genes Dev 16:6-21.

Chim CS, Wong ASY and Kwong YL (2003) Epigenetic inactivation of INK4/CDK/RB cell cycle pathway in acute leukemia. Ann Hematol 82:738-742.

Claus R and Lubbert M (2003) Epigenetic targets in hematopoietic malignancies. Oncogene 22:6489-96.
Dracopoli NC, Haine JL, Moir DT, Morton CC, Seidman CE, Seideman JG and Smith DR (1994) Current Protocols in Human Genetics. John Wiley \& Sons, New York, 750 pp.

Esteller M and Herman JG (2002) Cancer as an epigenetic disease: DNA methylation and chromatin alterations in human tumours. J Pathol 196:1-7.

French SW, Dawson DW, Miner MD, Doerr JR, Malone CS, Wall $\mathrm{R}$ and Teitell MA (2002) DNA methylation profiling: A new tool for evaluating hematologic malignancies. Clin Immunol 103:217-230.

Galm O, Herman JG and Baylin SB (2006) The fundamental role of epigenetics in hematopoietic malignancies. Blood Rev 20:1-13.

Garcia-Manero G, Daniel J, Smith TL, Kornblau SM, Lee M-S, Kantarjian HM and Issa J-PJ (2002). DNA methylation of multiple promoter-associated $\mathrm{CpG}$ islands in adult acute lymphocytic leukemia. Clin Cancer Res 8:2217-24.

Herman JG, Graff JR, Myohanen S, Nelkin BD and Baylin SB (1996) Methylation-specific PCR: A novel PCR assay for methylation status of $\mathrm{CpG}$ islands. Proc Natl Acad Sci USA 93:9821-6.

Hoshino K, Asou N, Okubo T, Suzushima H, Kiyokawa T, Kawano F and Mitsuya $\mathrm{H}$ (2002) The absence of the $p 15^{I N K 4 B}$ gene alterations in adult patients with precursor B-cell acute lymphoblastic leukaemia is a favourable prognostic factor. Br J Haematol 117:531-40.

Issa J-PJ, Baylin SB and Herman JG (1997) DNA methylation changes in hematologic malignancies: Biologic and clinical implications. Leukemia 11:S7-S11.

Jones PA (2003) Epigenetics in carcinogenesis and cancer prevention. Ann NY Acad Sci 983:213-9.

Jones PA and Baylin SB (2002) The fundamental role of epigenetic events in cancer. Nat Rev Genet 3:415-28. 
Kelly LM and Gilliland DG (2002) Genetics of myeloid leukemias. Annu Rev Genomics Hum Genet 3:79-98.

Laird PW (2003) The power and the promise of DNA methylation markers. Nat Rev Cancer 3:253-66.

Li L-C and Dahiya R (2002) MethPrimer: Designing primers for methylation PCRs. Bioinformatics 18:1427-31.

Markus J, Garin MT, Bies J, Galili N, Raza A, Thirman MJ, Beau MML, Rowley JD, Liu PP and Wolff L (2007) Methylation-independent silencing of the tumor suppressor INK4b (p15) by CBFß-SMMHC in acute myelogenous leukemia with inv (16). Cancer Res 67:992-1000.

Melki JR and Clark SJ (2002) DNA methylation changes in leukaemia. Semin Cancer Biol 12:347-57.

Melki JR, Vincent PC and Clark SJ (1999) Concurrent DNA hypermethylation of multiple genes in acute myeloid leukemia. Cancer Res 59:3730-40.

Mukai T and Sekiguchi M (2002) Gene silencing in phenomena related to DNA repair. Oncogene 21:9033-42.

Nephew KP and Huang TH-M (2003) Epigenetic gene silencing in cancer initiation and progression. Cancer Lett 190:25-33.

Pagliuca A, Gallo P and Lania L (2000) Differential role for $\mathrm{Sp} 1 / \mathrm{Sp} 3$ transcriptional factors in the regulation of the promoter activity of multiple cyclin-dependent kinase inhibitor genes. J Cell Biochem 76:360-7.

Rush LJ and Plass C (2002) Alterations of DNA methylation in hematologic malignancies. Cancer Lett 185:1-12.
Siegmund KD and Laird PW (2002) Analysis of complex methylation data. Methods 27:170-8.

Strathdee G and Brown R (2002) Aberrant DNA methylation in cancer: Potential clinical interventions. Exp Rev Mol Med 4:1-17.

Toyota M, Kopecky KJ, Toyota M-O, Jair K-W, Willman CL and Issa J-PJ (2001) Methylation profiling in acute myeloid leukemia. Blood 97:2823-9.

Verma M and Srivastava S (2002) Epigenetics in cancer: Implications for early detection and prevention. Lancet Oncol 3:755-63.

Wong IHN, Ng MHL, Huang DP and Lee JCK (2000) Aberrant p15 promoter methylation in adult and childhood acute leukemias of nearly all morphologic subtypes: Potential prognostic implications. Blood 95:1942-49.

Zago MA, Falcão RP and Pasquine R (2001) Hematologia: Fundamentos e Prática. 1st ed. Ateneu, São Paulo, 1042 pp.

\section{Internet Resources}

INCA (Instituto Nacional do Câncer), http://www.inca.gov.br (March 5, 2008).

Associate Editor: Emmanuel Dias Neto

License information: This is an open-access article distributed under the terms of the Creative Commons Attribution License, which permits unrestricted use, distribution, and reproduction in any medium, provided the original work is properly cited. 